\title{
Review
}

\section{Drosophila models of human neurodegenerative disease}

\author{
HYE Chan ${ }^{1}$ and NM Bonini ${ }^{*, 1}$ \\ 1 Howard Hughes Medical Institute, Department of Biology, University of \\ Pennsylvania, Philadelphia, Pennsylvania, PA 19104-6018, USA \\ * Corresponding author: NM Bonini, Howard Hughes Medical Institute, \\ Department of Biology, 415 S. University Avenue, University of Pennsylvania, \\ Philadelphia, Pennsylvania, PA 19104-6018, USA. Tel: 215-573-9267; \\ Fax: 215-898-8780; E-mail: nbonini@sas.upenn.edu
}

Received 3.7.00; revised 8.8.00; accepted 9.8.00

Edited by S Kumar

\begin{abstract}
Drosophila has provided a powerful genetic system in which to elucidate fundamental cellular pathways in the context of a developing and functioning nervous system. Recently, Drosophila has been applied toward elucidating mechanisms of human neurodegenerative disease, including Alzheimer's, Parkinson's and Huntington's diseases. Drosophila allows study of the normal function of disease proteins, as well as study of effects of familial mutations upon targeted expression of human mutant forms in the fly. These studies have revealed new insight into the normal functions of such disease proteins, as well as provided models in Drosophila that will allow genetic approaches to be applied toward elucidating ways to prevent or delay toxic effects of such disease proteins. These, and studies to come that follow from the recently completed sequence of the Drosophila genome, underscore the contributions that Drosophila as a model genetic system stands to contribute toward the understanding of human neurodegenerative disease. Cell Death and Differentiation (2000) 7, 1075-1080.
\end{abstract}

Keywords: Alzheimer's disease; Parkinson's disease; polyglutamine; molecular chaperones; genetics

Abbreviations: AD, Alzheimer's disease; APP, $\beta$-amyloid percursor protein; APPL, APP-like; FAD, familial Alzheimer's disease; hsp, heat shock protein; NI, nuclear inclusion; NMJ, neuromuscular junction; PD, Parkinson's disease; Psn, Presenilin; SCA, spinocerebellar ataxia; TM, transmembrane; UCHL1, ubiquitin C-terminal hydrolyase L1

\section{Introduction}

The success of biomedical research in the past few decades has provided the medical community with valuable information on numerous human diseases, including cancers and heart disease. Whereas human neurodegenerative diseases are among those most prominent, the application of genetics in simple model systems to address mechanisms of these diseases has only recently received attention. A number of major breakthroughs have been made in the last decade on these human diseases including the identification of a number of disease-related genes involved in Alzheimer's, Parkinson's and Huntington's diseases. The identification of the Huntington's Disease gene is the classical example of positional cloning of a human disease gene. ${ }^{1,2}$ With the cloning of such genes, pathogenic mechanisms of the diseases can then be addressed. ${ }^{3}$

Studies in model organisms have been found to be invaluable in elucidating the cellular and molecular basis of normal cellular processes, and what can go awry in disease pathogenesis. For example, transgenic and knock-out mouse models are a powerful approach to elucidate the molecular genetic basis of disease progression. ${ }^{4}$ However, genetic manipulations in the mouse are costly and time consuming, providing a need for even simpler systems with a greater array of genetic approaches that provide a faster time course. Such readily available systems that have been applied to elucidate molecular mechanisms of human neurodegenerative diseases include yeast, $C$. elegans and Drosophila (Figure 1). Genes between flies and humans are highly conserved, ${ }^{5}$ and Drosophila has a complex nervous system and displays complex behaviours such as learning and memory, making it a particularly attractive system for study of neuronal dysfunction and loss that proceeds from neurodegenerative disease. Here, we emphasize advances toward the understanding of select human neurodegenerative disorders through the use of Drosophila genetics. Other recent reviews emphasize additional aspects of cellular loss and degeneration in fly mutants and technical approaches, ${ }^{6-}$ 8 including other reviews of this issue.

\section{Alzheimer's disease}

Alzheimer's disease (AD) is one of the most common degenerative brain diseases, affecting $11 \%$ of the population over 65 years of age and $50 \%$ over the age of 85 (for reviews, please refer to $\left.{ }^{9,10}\right)$. AD disease brain tissue displays several unique pathological hallmarks including senile neuritic plaques and neurofibrillary tangles. Senile neuritic plaques are extracellular deposits consisting of $\beta$-amyloid peptides, while neurofibrillary tangles are cytoplasmic aggregates composed of the paired helical filaments of hyperphosphorylated tau (a brain-specific microtubule-associated protein). These abnormal deposits form primarily in brain regions that are essential for cognition and memory, with $A D$ patients typified by dementia.

A genetic basis for $A D$ was elucidated almost a decade ago after linkage between familial $A D$ patients and mutations in the $\beta$-amyloid precursor protein (APP) gene was found. The $A P P$ gene encodes a type I integral 
membrane protein (770 amino acids in length) that is susceptible to endoproteolytic cleavage through proteolytic pathways of $\alpha$-secretase and $\beta$-secretase. Cleavage of APP results in a $100-120 \mathrm{kDa} \mathrm{N}$-terminal extracellular fragment and a 10-12 kDa membrane bound fragment. The membrane bound fragment is further cleaved by $\gamma$ secretase and leads to the secretion of the p3 (from the $\alpha$-secretase pathway) or the $\mathrm{A} \beta 40$ (from the $\beta$-secretase pathway) fragment (for review, see ${ }^{11}$ ). Missense mutations

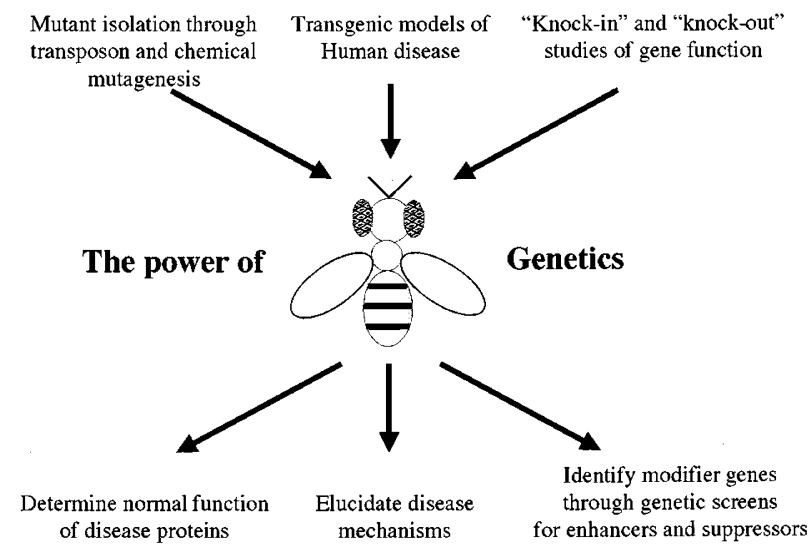

Figure 1 Approaches to addressing gene function in Drosophila. Function of fly genes homologous to human disease genes can be studied through classical mutagenesis, as well as transgenic and reverse genetic approaches ('knock-in'/'knock-out' technology). Transgenic models of disease allow mechanisms of disease progression to be addressed using the wealth of techniques available in Drosophila. Genetic screens allow the identification of genes that influence disease pathogenesis through modifier screens for enhancer and suppressor mutations in the $A P P$ gene identified in familial $A D(F A D)$ patients appear to favour the production of an amyloidogenic $A \beta 42$ peptide instead of $A \beta 40^{12} ; A \beta 42$ is prone to aggregation and is the main constituent of the senile neuritic plaques.

Another group of mutations associated with FAD patients falls into the Presenilin genes ( $P S N 1$ and $\left(P S N 2^{13}\right)$. Presenilin proteins possess eight proposed transmembrane domains and a large hydrophilic loop between transmembrane domains (TM) 6 and 7. Most Presenilin mutations are located around the TM domain encoding regions. ${ }^{14}$ Presenilin is suggested to be the $\gamma$-secretase ${ }^{15}$ or in close association with the $\gamma$-secretase, suggesting a mechanism by which altered Presenilin activity can lead to an increase in production of $\mathrm{A} \beta 42$.

\section{Functions of APP in flies}

Although the processing mechanism of APP has been studied extensively, the function of the APP protein and role of processing still remain elusive. Drosophila has an APP-like (APPL) orthologue, ${ }^{16}$ allowing functional analysis of the protein in the context of a developing nervous system (Table 1). Expression of the Appl gene in flies is observed mainly in the nervous system, starting from mid-embryogenesis through adulthood. ${ }^{17}$ At the protein level, APPL is first synthesized as a $145 \mathrm{kDa}$ membrane-associated protein, which is then rapidly cleaved into a $130 \mathrm{kDa}$ soluble fragment that lacks the $\mathrm{C}$-terminal domain. ${ }^{18}$

Flies that are homozygous for Appl null mutations are viable and display no gross morphological defects, suggesting that Appl is not essential for viability. However, behavioural defects in phototaxis are detected. ${ }^{19}$ These defects can be rescued by directed expression of

Table 1 Neurodegenerative genes in Drosophila

\begin{tabular}{|c|c|c|c|}
\hline Genes & Expression pattern & Mutant phenotype & Reference \\
\hline \multicolumn{4}{|l|}{ Transgenes } \\
\hline Human $\alpha$-synuclein & $\begin{array}{l}\text { Targeted expression } \\
\text { (GAL4/UAS) }\end{array}$ & $\begin{array}{l}\text { Progressive neurodegeneration/ } \\
\text { Behavioural defects }\end{array}$ & Feany and Bender 42 \\
\hline Human Huntingtin & $\begin{array}{l}\text { Targeted expression } \\
\text { (gmr) }\end{array}$ & $\begin{array}{l}\text { Progressive degeneration of } \\
\text { photoreceptor neurons }\end{array}$ & Jackson et al. ${ }^{45}$ \\
\hline Mammalian prion & Hsp70 promoter & No observable phenotype & Raeber et al. 56 \\
\hline $\begin{array}{l}\text { Wild-type Drosophila } \\
\text { Presenilin }\end{array}$ & $\begin{array}{l}\text { Targeted expression } \\
\text { (GAL4/UAS) }\end{array}$ & Apoptosis & Ye and Fortini 29 \\
\hline $\begin{array}{l}\text { Human mutant CuZn } \\
\text { Superoxide dismutase }\end{array}$ & $\begin{array}{l}\text { Targeted expression } \\
\text { (GAL4/UAS) }\end{array}$ & $\begin{array}{l}\text { Life span extension; partially } \\
\text { rescued SOD mutant phenotype }\end{array}$ & Elia et al. ${ }^{57}$ \\
\hline Human-SCA3 & $\begin{array}{l}\text { Targeted expression } \\
\text { (GAL4/UAS) }\end{array}$ & Progressive neurodegeneration & Warrick et al. ${ }^{46}$ \\
\hline \multicolumn{4}{|l|}{ Drosophila genes } \\
\hline Presenilin & $\begin{array}{l}\text { Ubiquitous, but expression is } \\
\text { enhanced in nervous tissues }\end{array}$ & Notch-like phenotype & $\begin{array}{l}\text { Ye et al. }{ }^{23} \\
\text { Guo et al. } 25\end{array}$ \\
\hline $\begin{array}{l}\text { Amyloid-precursor-protein-like } \\
\text { (APPL) }\end{array}$ & $\begin{array}{l}\text { Nervous system specific at all } \\
\text { developmental stages }\end{array}$ & $\begin{array}{l}\text { Phototaxis defects; decrease in } \\
\text { bouton number at larval NMJ }\end{array}$ & $\begin{array}{l}\text { Luo et al. }{ }^{19} \\
\text { Torroja et al. }{ }^{21}\end{array}$ \\
\hline UCHL1 & $\begin{array}{l}\text { Oogenesis/early embryogenesis } \\
\text { (by in-situ hybridization) }\end{array}$ & $\mathrm{N} / \mathrm{D}$ & Zhang et al. 58 \\
\hline Parkin & N/D & $\mathrm{N} / \mathrm{D}$ & Rubin et al. ${ }^{5}$ \\
\hline Huntingtin & $\begin{array}{l}\text { Widely during development (by } \\
\text { Northern blot) }\end{array}$ & $\mathrm{N} / \mathrm{D}$ & Li et al. ${ }^{59}$ \\
\hline $\begin{array}{l}\text { Spinocerebellar Ataxia type-2 } \\
\text { (SCA2) }\end{array}$ & $\mathrm{N} / \mathrm{D}$ & N/D & Rubin et al. ${ }^{5}$ \\
\hline SCA6 & $\mathrm{N} / \mathrm{D}$ & $\mathrm{N} / \mathrm{D}$ & Rubin et al. ${ }^{5}$ \\
\hline
\end{tabular}

$\mathrm{N} / \mathrm{D}$, Not determined 
the Appl transgene, but not by a mutant form of the protein that is unable to produce the cleaved $130 \mathrm{kDa}$ soluble APPL domain. This suggests that the cleavage event is at least in part essential for the normal cellular function of APPL. Importantly, behavioural defects of Appl mutants can also be rescued by a human $A P P$ transgene, suggesting that human APP and Drosophila APPL are at least partly functionally interchangeable. Moreover, upon expression in flies of a human APP transgene that contains only the integral membrane and $\mathrm{C}$-terminal domains (including the $\mathrm{A} \beta$ moiety) in flies, $\mathrm{A} \beta 40$ is detected by Western blot, suggesting that Drosophila possesses functional APP processing machinery. ${ }^{20}$ This finding provides the foundation for genetic approaches in Drosophila to elucidate additional details of APP processing.

In addition to expression in the central nervous system, APPL protein is detected at the neuromuscular junction (NMJ) and its accumulation is dependent on synaptic activity. ${ }^{21}$ When synaptic activity is enhanced, APPL is found to be densely localized at the NMJ. However, in the absence of APPL, the number of synaptic boutons (the interface between motor neurons and muscles) is reduced. In contrast, when APPL is over-expressed at the NMJ, extra numbers of boutons with abnormal appearance are observed. ${ }^{21}$ These results suggest that localization of APPL may be an activity-dependent event, and that APPL is also involved in the regulation of synaptic morphology. Another role of APPL in vesicular trafficking is revealed by monitoring axonal transport of a synaptic protein, synaptotagmin. ${ }^{22}$ Normally, synaptotagmin is transported through motor axons and localized at the NMJ. Upon overexpression of APPL, retention of synaptotagmin along motor axons is observed, suggesting a disruption of normal axonal transport.

\section{The role of Presenilin in Drosophila}

A critical aspect of $A D$ research is to elucidate mechanisms of APP processing and identify genes that are involved in the production of the amyloidogenic $\mathrm{A} \beta 42$ peptide. Analogous to APP processing, Presenilins have recently been shown to be involved in proteolytic processing of Notch - a role revealed by study of Presenilin function in Drosophila. ${ }^{23-26}$ A role of Presenilin genes in Notch pathways was first revealed by studies in $C$. elegans of the analogous lin-12 pathway. ${ }^{27}$ In Drosophila, Presenilin mutants display a partial Notch-like phenotype ${ }^{23}$ and mutations in Presenilin enhance dominant Notch phenotypes, ${ }^{25}$ suggesting that Presenilin and Notch are involved in the same pathway in flies. Directed expression of Presenilin to the fly eye causes disruption of the normal eye structure, due to death of cells through apoptotic pathways. The phenotype can be suppressed by either up-regulation of the Notch pathway or by co-expression of the viral antiapoptotic gene P35. Compared to wild-type Presenilin, mutations of Presenilin analogous to those observed in human FAD show less activity than normal, suggesting that FAD mutations in Presenilin are loss-of-function mutations. ${ }^{28,29}$

The Drosophila Presenilin protein shows $\sim 50 \%$ sequence identity to its human counterpart, and like human
Presenilins, undergoes proteolytic cleavage to give rise to a $30-35 \mathrm{kDa} N$-terminal and $25 \mathrm{kDa}$ C-terminal fragments. ${ }^{25,30}$ Two aspartate residues (one from each cleaved fragment), that are thought to be critically involved in $\gamma$-secretase function of human Presenilins, are also conserved in the fly protein.

\section{Parkinson's disease}

Parkinson's disease (PD) is the most common movement disorder, affecting approximately 1 million people in the United States. ${ }^{31}$ This disease is mostly sporadic and typically affects people that are between 50 and 60 years of age. A small fraction of PD cases have been linked to mutations in specific genes, including the $\alpha$-synuclein, parkin and ubiquitin C-terminal hydrolase L1 (UCHL1) genes. ${ }^{32-35}$ Cytoplasmic aggregates called Lewy bodies are usually found in the substantia nigra of brain tissue, except for a few variant forms of PD. Dopaminergic neurons are the type of nerve cells that are most susceptible to degeneration in PD. Not only have mutations in the $\alpha$-synuclein gene been linked to PD, $\alpha$ synuclein protein is the major building block of Lewy bodies ${ }^{36}$ in both familial and sporadic PD, suggesting similar mechanisms of disease pathology.

$\alpha$-Synuclein is a small soluble protein (140 amino acids in length) that contains six $\mathrm{N}$-terminal degenerate KTKEGV repeats and an acidic C-terminal domain. The protein is transported via two axonal transport mechanisms in neurons (fast and slow components ${ }^{37}$ ). The first four N-terminal imperfect repeats have been demonstrated to be essential for axonal transport of $\alpha$-synuclein. ${ }^{37}$ Under defined conditions in vitro, $\alpha$-synuclein is able to form insoluble filaments with $\beta$-sheet structure. ${ }^{38,39}$ Mutations in $\alpha$ synuclein identified in familial PD patients are A53T and A30P. ${ }^{32,33}$ In vitro, the A53T mutant protein displays a higher rate of insoluble filament assembly compared to wildtype $\alpha$-synuclein, ${ }^{38}$ whereas A30P impairs the ability of $\alpha$ synuclein to bind to brain vesicles in rat brain. ${ }^{37}$ Lewy body formation may be achieved by enhancing the rate of $\beta$-sheet insoluble filament assembly through $\alpha$-synuclein mutation, sporadic effects, or defective axonal transport of the protein causing local accumulation. Since wild-type $\alpha$-synuclein protein forms insoluble filaments (Lewy bodies) in sporadic PD in the absence of $\alpha$-synuclein mutation, this suggests that other yet-to-be-defined genetic factors ${ }^{40}$ as well as environmental factors, for example cellular redox conditions, ${ }^{41}$ are likely to contribute to disease pathogenesis.

\section{Modelling PD in flies}

Expression of human $\alpha$-synuclein in flies does not cause any gross morphological changes, but leads to selective loss of dopaminergic neurons in the adult brain over time. ${ }^{42}$ The cellular loss displays specificity in that serotonic neurons, in contrast to dopaminergic neurons, are unaffected. Loss of dopaminergic neurons in aged flies is observed upon expression of normal as well as mutant forms of $\alpha$-synuclein (A30P and A53T), thus displaying no selective characteristics of the mutant forms of the protein in flies in vivo. 
Transgenic flies expressing $\alpha$-synuclein also display accumulation of protein in cytoplasmic inclusions. The aggregates are observed in a sequential manner, with diffuse and cytoplasmic staining present in young brain tissue and protein accumulations noted at later stages, prior to neuronal loss. These cytoplasmic inclusions appear to be present in a more widespread manner than only dopaminergic neurons. A lack of spatial correlation between Lewy body formation and loss of dopaminergic neurons is also observed in patients with diffuse Lewy body disease. This possible selective vulnerability of dopaminergic neurons to human $\alpha$-synuclein in flies may reflect a special property of $\alpha$-synuclein in dopaminergic neurons or merely sensitivity of dopaminergic neurons to ectopic insults. Pan-neural expression of $\alpha$-synuclein (wild-type, A53T and A30P mutants) results in premature loss of climbing ability, suggesting that transgenic expression of synuclein impairs locomotor ability in flies. A link between these behavioural defects and loss of dopaminergic neurons remains to be established.

\section{Human polyglutamine disease}

Numerous cellular proteins contain stretches of repeats of the amino acid glutamine. A class of human disease has been found to be associated with expansion of such polyglutamine domains. To date, at least eight human neurological diseases are caused by polyglutamine expansion (typically from a normal range of $4-$ 36 residues to a pathogenic range of 36-306 residues, with the exception of SCA6) in the respective cellular proteins. ${ }^{3}$ These diseases are dominantly inherited (except for spinobulbar muscular atrophy which is X-linked), suggesting that the expanded polyglutamine domain confers a novel toxic property on the cellular proteins. Moreover, expanded polyglutamine proteins form aggregates, typically in the form of nuclear inclusions (NIs). Except for the polyglutamine, no other sequence homology is found between these different human disease proteins; most of them are novel proteins with currently unknown cellular functions.

Nuclear inclusions have been proposed to be the cause of neurotoxicity of polyglutamine diseases, however a direct relationship between aggregate formation and neurotoxicity is still lacking. Other models have also been suggested to explain toxicity of the polyglutamine proteins. ${ }^{43}$ Aggregation of mutant proteins is clearly a characteristic of the disease proteins, indicating that these abnormal aggregates, whereas perhaps not causal, reflect a novel property gained by the mutant protein.

\section{Drosophila models for human polyglutamine disease}

Polyglutamine-induced neurodegeneration has been recapitulated in model organisms using transgenic techniques. $^{44}$ In Drosophila, two disease models have been generated $^{45,46}$ (Figure 2), as well as models using pure polyglutamine domains or an expanded polyglutamine domain inserted into a normal cellular protein. ${ }^{47,48}$ Polyglutamine disease models in flies include an MachadoJoseph Disease (MJD) disease model and a Huntington's
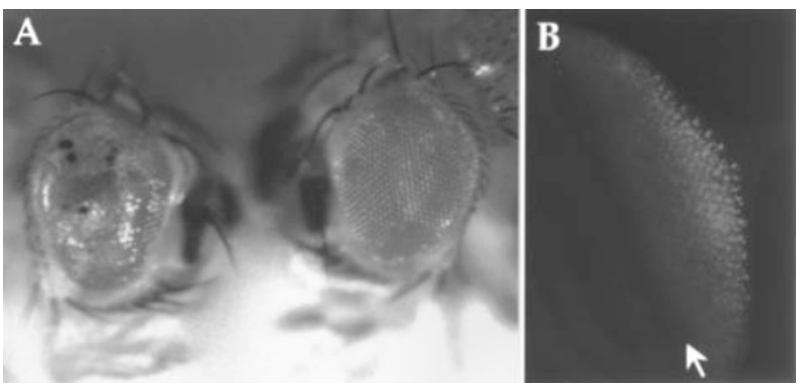

Figure 2 A model for human neurodegenerative disease in Drosophila. (A) Left is a fly expressing a human mutant disease gene for the neurodegenerative disease Machado-Joseph disease in the fly eye. The mutant protein induces severe degeneration, illustrated by the lack of pigmentation and collapse of the eye. Right is a fly expressing the same human mutant disease gene, but now also expressing a human gene encoding the molecular chaperone Hsp70. Although the disease protein is still present, neurodegeneration does not occur, demonstrating the power of Drosophila to elucidate potential suppressor mechanisms to prevent neurodegenerative disease. (B) Abnormal aggregates formed upon expression of the human mutant disease protein in developing eye tissue. Many different human neurodegenerative diseases are associated with abnormal protein aggregates, including $A D, P D$ and polyglutamine disease. As illustrated here, not only the neurodegenerative phenotype, but also abnormal protein aggregation, is modelled in Drosophila. Arrow marks morphogenetic furrow

Disease model. By expressing a truncated version of the pathogenic human MJD gene (also called SCA3, spinocerebellar ataxia type 3 ) in the fly, Warrick et al. ${ }^{46}$ observed lateonset progressive degeneration. Using a truncated form of the human Huntington's disease gene, Jackson et al. ${ }^{45}$ directed expression to the fly eye, showing progressive loss of photoreceptor neurons. In humans, severity of disease is proportional to the length of the expanded polyglutamine run, with longer expansions causing an earlier onset, more severe disease. In Drosophila, degeneration is also observed to be earlier onset and more severe with a run of 102 glutamines compared to 75 glutamines, although a quantitative comparison of the expression levels between the two transgenes was not reported. ${ }^{45}$ Co-expression of mutant disease proteins with the viral anti-apoptotic gene $P 35$, has little or no effect on degeneration, suggesting that polyglutamine-induced cell loss appears not to be greatly influenced by P35-inhibitable cell death pathways.

Both Kazemi-Esfarjani and Benzer, ${ }^{47}$ and Marsh et al. ${ }^{48}$ have shown that merely a run of polyglutamine peptide is sufficient to induce degeneration in the fly nervous system. Marsh et al. ${ }^{48}$ showed that addition of non-polyglutamine sequence at the ends of a polyglutamine run reduces the toxicity of the peptides, confirming that the toxicity of polyglutamine-induced neurodegeneration is, at least in part, dependent upon protein context. The authors also expanded a polyglutamine domain from 28 to 108 residues within an endogenous fly protein, Dishevelled (Dsh), and expressed it via endogenous dsh promoter elements. When compared to the activity of normal Dsh protein, the 'expanded Dsh' partially rescued the dsh mutant phenotype, suggesting that polyglutamine expansion does not completely abolish normal protein activity, but that some degree of normal cellular function is retained despite polyglutamine expansion. 


\section{Using fly genetics to elucidate mechanisms of toxicity and prevent neurodegeneration}

The power of modelling human neurodegenerative disease in Drosophila is to pioneer ways to understand degenerative mechanisms and effect suppression. Toward this end, molecular chaperones have been revealed as powerful suppressors of neurodegeneration in Drosophila. Heat shock proteins (Hsps) comprise a large group of proteins that are rapidly induced during stress conditions. Induced Hsps serve different functions, including assistance in the folding of misfolded proteins and degradation of irreparably damaged proteins. ${ }^{49,50} \mathrm{Hsp} 70$ is the main stress-induced molecular chaperone in Drosophila. By expressing a human Hsp70 transgene in flies, Warrick et al ${ }^{51}$ were able to suppress neurodegeneration in the Drosophila MJD disease model (Figure 2). Moreover, expression of a dominant-negative form of constitutive Hsp70 enhanced degeneration, suggesting a central role of Hsp70 in disease progression. Interestingly, in the situation when polyglutamine toxicity is ameliorated, the protein remains aggregated as visualized by immunohistochemistry, suggesting that reduced toxicity is not correlated with gross loss of NIs. ${ }^{51}$

Kazemi-Esfarjani and Benzer ${ }^{47}$ found additional suppressors through a mis-expression screen, looking for modifiers of the eye degenerative phenotype caused by ectopic expression of a pathogenic polyglutamine peptide. Two suppressors were defined that belong to a second class of chaperone family. One of them is a fly Hsp40 orthologue dHdj1. Hsp40 proteins assist Hsp70 in protein folding by stimulating the ATPase activity and substrate binding of Hsp70. ${ }^{52}$ Up-regulation of $\mathrm{dHdj} 1$ or other J-domain containing proteins may therefore increase the efficiency of the protein folding function of $\mathrm{Hsp} 70$ and hence modulate folding of polyglutamine proteins. These studies illustrate the power of Drosophila genetics to elucidate potential mechanisms of suppression of neurodegeneration.

\section{The post-genomic era of biomedical Drosophila research}

With the recent completion of the Drosophila genomic sequence, comparative genomic analysis has led to the discovery of several previously unidentified disease-related genes including orthologues of human SCA2 (the gene mutated in spinocerebellar ataxia type 2) and parkin (juvenile onset parkinsonism). ${ }^{5}$ Both classical and reverse Drosophila genetics have proven to be invaluable tools in elucidating underlying mechanisms of many cellular processes, as illustrated here. Moreover, with the recent establishment of a gene targeting technique in flies, ${ }^{53}$ it should be possible to target endogenous wild-type copies of 'disease genes' in the fly genome for inactivation (knock-out); defined mutations can also be 'engineered' (knock-in) into respective endogenous genes, e.g. extra glutamine residues in Sca2, huntingtin, to create gain-of-function models. Potentially, human disease genes can also be used to replace endogenous copies of their Drosophila orthologues, allowing expression of the human disease gene under the control of endogenous enhancer/promoter elements of the fly.

Gene expression profiles in disease conditions are always different from normal conditions. ${ }^{54}$ Monitoring changes of gene expression profiles in disease and nondisease conditions may lead us further toward the understanding of molecular mechanisms of disease pathogenesis. With the whole 'dictionary of the fruit fly' in hand, genes that have altered expression patterns can be determined in vivo through the use of DNA microarray analysis. ${ }^{55}$ As a step forward, in vivo analysis of gene expression profiles from a suppressed (e.g. Hsp70 suppression) or enhanced condition, or other more complicated genetic scenarios, will provide us with additional handles into the molecular mechanisms of disease pathogenesis in a whole organism.

For almost a century, fruit flies have been providing a useful tool to study various different subjects: from the chemical basis of mutagenesis, to the definition of genes; from developmental biology, to animal behaviour. The ability to use Drosophila as a powerful tool to approach pathogenic disease mechanisms of human diseases speaks to a tremendous application in biomedical research.

\section{Acknowledgements}

HYE Chan is supported by the Wellcome Trust. NM Bonini receives funding from the HDSA Coalition for the Cure, Hereditary Disease Foundation, the David and Lucile Packard Foundation, and the NIH. NM Bonini is an Assistant Investigater of the Howard Hughes Medical Institute.

\section{References}

1. Gusella JF, Wexler NS, Conneally PM, Naylor SL, Anderson MA, Tanzi RE Watkins PC, Ottina K, Wallace MR, Sakaguchi AY, Young AB, Shoulson I, Bonilla E and Martin JB (1983) A polymorphic DNA marker genetically linked to Huntington's disease. Nature 306: 234-238

2. The Huntington's disease collaborative research group (1993) A novel gene containing a trinucleotide repeat that is expanded and unstable on Huntington's disease chromosomes. Cell 72: 971-983

3. Zoghbi HY and Orr HT (2000) Glutamine repeats and neurodegeneration. Annu. Rev. Neurosci. 23: 217-237

4. Lin X, Cummings CJ and Zoghbi HY (1999) Expanding our understanding of polyglutamine disease through mouse models. Neuron. 24: 499-502

5. Rubin GM, Yandell MD, Wortman JR, GaborMiklos GL, Nelson CR, Hariharan IK, Fortini ME, Li PW, Apweiler R, Fleischmann W, Cherry JM, Henikoff S, Skupski MP, Misra S, Ashburner M, Birney E, Boguski MS, Brody T, Brokstein P, Celniker SE, Chervitz SA, Coates D, Cravchik A, Gabrielian A, Gale RF, Gelbart WM, George RA, Goldstein LSB, Gong F, Guan P, Harris NL, Hay BA, Hoskins RA, LiJ, Li Z, Hynes RO, Jones SJM, Kuehl PM, Lemaitre B, Littleton JT, Morrison DK, Munghall C, O'Farrell PH, Pickeral OK, Shue C, Vosshall LB, Zhang J, Zhao Q, Zheng XH, Zhong F, Zhong W, Gibbs R, Venter JC, Adams MD and Lewis S (2000) Comparative genomics of the eukaryotes. Science 287: 2204-2215

6. Mutsuddi M and Nambu JR (1998) Neural disease: Drosophila degenerates for a good cause. Curr. Biol. 8: R809-R811

7. Thomas BJ and Wassarman DA (1999) A fly's eye view of biology. Trends Genet. 15: $184-190$

8. Fortini ME and Bonini NM (2000) Modeling human neurodegenerative diseases in Drosophila: on a wing and a prayer. Trends Genet. 16: 161-167

9. Price DL, Tanzi RE, Borchelt DR and Sisodia SS (1998) Alzheimer's Disease: Genetic studies and transgenic models. Annu. Rev. Genet. 32: 461-493

10. Vickers JC, Dickson TC, Adlard PA, Saunders HL, King CE and McCormack G (2000) The cause of neuronal degeneration in Alzheimer's disease. Prog. Neurobiol. 60: 139-165 
11. De Strooper B and Annaert W (2000) Proteolytic processing and cell biologica functions of the amyloid precursor portein. J. Cell Sci. 113: 1857-1870

12. Citron M, Oltersdorf $T$, Haass $C$, McConlogue L, Hung AY, Seubert $P$, VigoPelfrey C, Lieberburg I and Selkoe DJ (1992) Mutation of the beta-amyloid precursor protein in familial Alzheimer's disease increases beta-protein production. Science. 360: 672-674

13. Sherrington R, Rogaev E, Liang Y, Rogaeva E, Levesque G, Ikeda M, Chi H, Lin C, Holman K, Tsuda T, Mar L, Foncin J-F, Bruni A, Montesi M, Sorbi S, Rainero I, Pinessi L, Nee L, Chumakov I, Pollen D, Brookes A, Sanseau P, Polinsky R, Wasco W, da Silva H, Haines J, Pericak-Vance M, Tanzi R, Roses A, Fraser P, Rommens J and St. George-Hyslop P (1995) Cloning of a gene bearing missense mutations in early-onset familial Alzheimer's disease. Nature. 375: 754-760

14. St. George-Hyslop PH (1999) Molecular genetics of Alzheimer Disease. Sem. Neurol. 19: 371-383

15. Li Y, Xu M, Lai M, Huang Q, Castro JL, DiMuzio-Mower J, Harrison T, Lellis C Nadin A, Neduvelil JG, Register RB, Sardana MK, Shearman MS, Smith AL, Sh $X$, Yin Y, Shafer JA and Gardell SJ (2000) Photoactivated $\gamma$-secretase inhibitors directed to the active site covalently label presenilin 1. Nature 405: 689-694

16. Rosen DR, Martin-Morris L, Luo LQ and White K (1989) A Drosophila gene encoding a protein resembling the human beta-amyloid protein precursor. Proc. Natl. Acad. Sci. USA 86: 2478-2482

17. Martin-Morris LE and White K (1990) The Drosophilatranscriptencoded by the $\beta$ amyloid protein precursor-like gene is restricted to the nervous system. Development. 110: 185-195

18. Luo L, Martin-Morris LE and White K (1990) Identification, secretion, and neural expression of APPL, a Drosophila protein similar to human amyloid protein precursor. J. Neurosci. 10: $3849-3861$

19. Luo L, Tully T and White K (1992) Human amyloid precursor protein ameliorates behavioral deficit of flies deleted for App/gene. Neuron. 9: 595-605

20. Fossgreen A, Brukner B, Czech C, Masters CL, Beyreuther K and Paro R (1998) Transgenic Drosophila expressing human amyloid precursor protein show $\gamma$ secretase activity and a blistered-wing phenotype. Proc. Natl. Acad. Sci. USA. 95: $13703-13708$

21. Torroja L, Packard M, Gorczyca M, White Kand Budnik V (1999) The Drosophila $\beta$-amyloid precursor protein homolog promotes synapse differentiation at the neuromuscular junction. J. Neurosci. 19: 7793-7803

22. Torroja L, Chu H, Kotovsky I and White K (1999) Neuronal overexpression of APPL, the Drosophila homologue of the amyloid precursor protein (APP), disrupts axonal transport. Curr. Biol. 9: 489-492

23. Ye Y and Fortini ME (1998) Characterization of Drosophila Presenilin and its colocalization with Notch during development. Mech. Dev. 79: 199-211

24. Ye Y, Lukinova N and Fortini ME (1999) Neurogenic phenotypes and altered Notch processing in Drosophila Presenilin mutants. Nature 398: 525-529

25. Guo Y, Livne-Bar I, Zhou L and Boulianne GL (1999) Drosophila Presenilin is required for neuronal differentiation and affects Notch subcellular localization and signaling. J. Neurosci. 19: 8435-8442

26. Struhl G and Greenwald I (1999) Presenilin is required for activity and nuclear access of Notch in Drosophila. Nature. 398: 522-525

27. Levitan Dand Greenwald I (1995) Facilitation of lin-12 mediated signalling by sel-12, a Caenorhabditis elegans S182 Alzheimer's disease gene. Nature. 377: 351-354

28. Levitan D, Doyle TG, Brousseau D, Lee MK, Thinakaran G, Slunt HH, Sisodia SS and Greenwald I (1996) Assessment of normal and mutant human Presenilin function in Caenorhabditis elegans. Proc. Natl. Acad. Sci. USA. 93: 14940-14944

29. Ye Y and Fortini ME (1999) Apoptotic activities of wild-type and Alzheimer's disease-related mutant Presenilin in Drosophila melanogaster. J. Cell. Biol. 146 $1351-1364$

30. Nowotny P, Gorski SM, Han SW, Philips K, Ray WJ, Nowotny V, Jones CJ, Clark RF, Cagan RL and Goate AM (2000) Posttranslational modification and plasma membrane localization of the Drosophila melanogaster Presenilin. Mol. Cell. Neurosci. 15: 88-98

31. Olanow CW and Tatton WG (1999) Etiology and pathogenesis of Parkinson's disease. Annu. Rev. Neurosci. 22: 123-144

32. Polymeropoulos MH, Lavedan C, Leroy E, Ide SE, Dehejia A, Dutra A, Pike B, Root $\mathrm{H}$, Rubenstein J, Boyer R, Chandrasekharappa S, Athanassiadou A, Papapetropoulos T, Johnson WG, Lazzarini AM, Duvoisin RC, Di lorio G, Golbe $\mathrm{LI}$ and Nussbaum RL (1997) Mutation in the $\alpha$-synuclein gene identified in families with Parkinson's disease. Science 276: 2045-2047

33. Kruger R, Kuhn W, Muller T, Woitalla D, Graeber M, Kosel S, Przuntek H, Epplen JT, Schols L and Riess O (1998) Ala30Pro mutation in the gene encoding alphasynuclein in Parkinson's disease. Nat. Genet. 18: 106-108
34. Kitada T, Asakawa S, Hattori N, Matsumine H, Yamamura Y, Minoshima S, Yokochi M, Mizuno Y and Shimizu N (1998) Mutations in the parkin gene cause autosomal recessive juvenile parkinsonism. Nature. 392: 605-608

35. Leroy E, Boyer R, Auburger G, Leube B, Ulm G, Mezey E, Harta G, Brownstein MJ, Jonnalagada S, Chernova T, Dehejia A, Lavedan C, Gasser T, Steinbach P, Wilkinson KD and Polymeropoulos MH (1998) The ubiquitin pathway in Parkinson's disease. Nature. 395: 451-452

36. Spillantini MG, Schmidt ML, Lee VM, Trojanowski JQ, Jakes R and Goedert M (1997) Alpha-synuclein in Lewy bodies. Nature. 388: 839-840

37. Jensen PH, Nielsen MS, Jakes R, Dotti CG and Goedert M (1998) Binding of $\alpha$ synuclein to brain vesicles is abolished by familial Parkinson's disease mutation. J. Biol. Chem. 273: 26292-26294

38. Serpell LC, Berriman J, Jakes R, Goedert M and Crowther RA (2000) Fiber diffraction of synthetic $\alpha$-synuclein filaments shows amyloid-like cross- $\beta$ conformation. Proc. Natl. Acad. Sci. USA 97: 4897-4902

39. Giasson BI, Uryu K, Trojanowski JQ and Lee VM (1999) Mutant and wild type human $\alpha$-synuclein assemble into elongated filaments with distinct morphologies in vitro. J. Biol. Chem. 274: 7619-7622

40. Gasser T, Muller-Myhsok B, Wszolek ZK, Oehlmann R, Calne DB, Bonifati V, Bereznai B, Fabrizio E, Vieregge $P$ and Horstmann RD (1998) A susceptibility locus for Parkinson's disease maps to chromosome 2p13. Nat. Genet. 18: 262-265

41. Jenner P (1998) Oxidative mechanisms in nigral cell death in Parkinson's disease. Mov. Disord. 13 suppl. 1: 24-34

42. Feany MB and Bender WW (2000) A Drosophila model of Parksinson's disease. Nature. 404: 394-398

43. Monoi H, Futaki S, Kugimiya S, Minakata H and Yoshihara K (2000) Poly-Lglutamine forms cation channels: relevance to the pathogenesis of the polyglutamine diseases. Biophys. J. 78: 2892-2899

44. Lin X, Cummings CJ and Zoghbi HY (1999) Expanding our understanding of polyglutamine diseases through mouse models. Neuron. 24: 499-502

45. Jackson G, Salecker I, Dong X, Yao X, Arnheim N, Faber P, MacDonald M and Zipursky S (1998) Polyglutamine-expanded human Huntingtin transgenes induce degeneration of Drosophila photoreceptor neurons. Neuron. 21: 633642

46. Warrick JM, Paulson H, Gray-Board GL, Bui QT, Fischbeck K, Pittman RN and Bonini NM (1998) Expanded polyglutamine protein forms nuclear inclusions and causes neural degeneration in Drosophila. Cell 93: 939-949

47. Kazemi-Esfarjani P and Benzer S (2000) Genetic suppression of polyglutamine toxicity in Drosophila. Science 287: $1837-1840$

48. Marsh JL, Walker H, Theisen H, Zhu Y, Fielder T, Purcell J and Thompson LM (2000) Expanded polyglutamine peptides alone are intrinsically cytotoxic and cause neurodegeneration in Drosophila. Human Mol. Genet. 9: 13-25

49. Hartl $F$ (1996) Molecular chaperones in cellular protein folding. Nature. 381: $571-580$

50. Bukau Band Horwich A (1998) The Hsp70 and Hsp60 chaperone machines. Cell. 92: $351-366$

51. Warrick JM, Chan HYE, Gray-Board GL, Chai Y, Paulson HL and Bonini NM (1999) Suppression of polyglutamine-mediated neurodegeneration in Drosophila by the molecular chaperone HSP70. Nat. Genet. 23: 425-428

52. Suh W, Lu CZ and Gross CA (1999) Structural features required for the interaction of the Hsp70 molecular chaperone DnaK with its cochaperone DnaJ. J. Biol. Chem. 274: 30534-30539

53. Rong YS and Golic KG (2000) Gene targeting by homologous recombination in Drosophila. Science. 288: 2013-2018

54. Lin X, Antalffy B, Kang D, Orr HT and Zoghbi HY (2000) Polyglutamine expansion down-regulates specific neuronal genes before pathologic changes in SCA. Nat. Neurosci. 3: 157-163

55. White KP, Rifkin SA, Hurban P and Hogness DS (1999) Microarray analysis of Drosophila during metamorphosis. Science 286: 2179-2184

56. Raeber AJ, Muramoto T, Kornberg TB, Prusiner SB (1995) Expression and targeting of Syrian hamster pion protein induced by heat shock in transgenic Drosophila melanogaster. Mech. Dev. 51:317-327

57. Elia AJ, Parkes TL, Kirby K, St. George-Hyslop P, Boulianne GL, Phillips JP, Hilliker AJ (1999) Expression of human FALS SOD in motorneurons of Drosophila. Free Rad. Biol. Med. 26: 1332-1338

58. Zhang N, Wilkinson K, Bownes M (1993) Cloning and analysis of expression of a ubiquitin carboxyl terminal hydrolase expressed during oogenesis in Drosophila melanogaster. Dev. Biol. 157:214-223

59. Li Z, Karlovich CA, Fish MP, Scott MP, Myers RM (1999) A putative Drosophila homolog of the Huntingdon's disease gene. Hum. Mol. Gen. 8: 1807-1815 